\title{
In Vitro Fluoride Induced Genotoxic Effect on Human Blood Lymphocyte Cells and its Amelioration by Emblica Officinalis Extract
}

\author{
Swati B Thakur*, Mandava V Rao \\ From International Conference on Human Genetics and 39th Annual Meeting of the Indian Society of \\ Human Genetics (ISHG) \\ Ahmadabad, India. 23-25 January 2013
}

\section{Background}

Fluoride is a widespread industrial pollutant. Although, acute and chronic exposure of fluoride results in adverse health effects, in vitro studies demands for further evidences to conclude on the role of $\mathrm{F}$ as genotoxic agent. We have investigated the genotoxic properties of fluoride on peripheral blood lymphocyte cells and evaluated the protective effect of Emblica officinalis (Amla) against fluoride toxicity.

\section{Materials and Methods}

Peripheral blood lymphocytes were cultured and treated with different concentrations of fluoride $(17 \mu \mathrm{M}, 34 \mu \mathrm{M}$, and $51 \mu \mathrm{M})$ and supplement with amla extract $(20 \mu \mathrm{g})$ for the study of various genotoxic parameters such as sister chromatid exchanges (SCEs) and cytokinesis block micronucleus (CBMN) assay. To rule out the antioxidant properties of amla, indices like 1,1-diphenyl-2picrylhydrazyl (DPPH) assay and High performance thin layer chromatography (HPTLC) were done.

\section{Results}

Fluoride exhibited a significant increase in SCEs per metaphase plate $(\mathrm{p}<0.001)$ and SCEs per chromosome $(p<0.05)$. Similarly, cell cycle proliferative index significantly decrease $(\mathrm{p}<0.001)$ in a dose-dependent manner in the three fluoride dose groups. Genotoxic indices such as nuclear deformities and frequency of micronucleus significantly $(p<0.001)$ elevated with increased fluoride concentration. Furthermore, nuclear division index (NDI) and cell viability also noticed to be declined

\footnotetext{
* Correspondence: zooldeptgu@satyam.net.in

Human Genetic Unit, Department of Zoology, School of Sciences, Gujarat University, Ahmedabad, Gujarat, India
}

\section{and take full advantage of:}

- Convenient online submission

- Thorough peer review

- No space constraints or color figure charges

- Immediate publication on acceptance

- Inclusion in PubMed, CAS, Scopus and Google Scholar

- Research which is freely available for redistribution 